\title{
剛飛翔体の高速衝突を受けた鉄筋コンクリート造壁の 構造耐火性に関する実験的検討 \\ AN EXPERIMENTAL STUDY ON STRUCTURAL FIRE BEHAVIOR OF REINFORCED CONCRETE WALL AFTER HIGH VELOCITY IMPACT OF HARD PROJECTILE
}

\author{
森田武*, 別府万寿博**, 鈴木 誠*** \\ Takeshi MORITA, Masuhiro BEPPU and Makoto SUZUKI
}

\begin{abstract}
Projectiles would be released by an accident such as damage of turbine blades, and impinge on structures. Flying objects such as airplanes are also possible to be impact projectiles. These accidents occasionally cause fire, if there are fire load such as oil, fuel and any other combustible materials. This research focuses on the structural fire behavior of load bearing reinforced concrete walls exposed to fire after high velocity impact of a hard projectile. Impact and fire experiments on small scale reinforced concrete walls were carried out. The results show the influence of local damage and the advantage of short fiber reinforced concrete against fire.
\end{abstract}

Keywords : High velocity impact, Hard projectile, Local damage, Reinforced concrete wall, Fire resistance, Short fiber reinforcement 高速衝突，剛飛翔体，局部破壊，鉄筋コンクリート造壁，而火性，短繊維補強

\section{1. はじめに}

近年，爆発事故や自然災害によって衝撃的な荷重がコンクリート 構造物に作用し，損傷や破壊を生じるケースが増加している。 衝撃荷重によるコンクリート構造物の破壊は，全体破壊と局部破 壊に分類できる 1)。飛翔体がコンクリート構造物に高速度で衝突す ると，衝突条件によって，表面破壊（衝突面の破壊），裏面剥離（衝 突面と反対面のコンクリートの剥離), 貫通 (表面破壊と裏面剥離が 連結して飛翔体が裏面側一貫通する破壊）等の局部破壊を生じる 2)。 局部破壊は構造部材の剛性や強度を低下させるとともに，裏面剥離 や貫通に至る場合には裹面に飛散物を生じる。飛散物から構造物内 の人命や財産を守るためには裏面剥離や貫通を防止する必要があり, 著者らは, 裏面剥離の防止対策技術としてコンクリートの短繊維補 強に着目して，高速衝突実験等によってその有効性を確認した ${ }^{3)}$ 。

一方, 発電施設等でのタービンブレードの破損・飛散による衝突 と火災，あるいは一般の構造物への航空機の衝突と火災などの事故 事例があるように, 衝突作用後の構造物の内部あるいは外部におい て, 燃料・油などといった種々の可燃物の燃焼による火災が発生す る可能性がある。衝突後の火災に対して構造物内の人命や財産を守 るには, 衝突作用とその後の火災作用の双方に対して, 部材・構造 体の構造安定性を確保するとともに, 火災区画以外の区画への延焼 あるいは屋外から屋内への延焼を防止しなければならない。そのた
めには，まず，局部破壊したコンクリート構造体が火災加熱を受け た場合の温度性状（遮熱性・遮炎性や部材温度の経時変化など）や 構造耐火性（非損傷性や変形の経時変化など）を把握する必要があ る。これに対して, 著者らは, 剛飛翔体の高速衝突を受けた後, 衝 突面側から火災加熱を受けるコンクリート板の温度性状に関して, 実験的・解析的検討を行い局部破壊の影響を把握した ${ }^{4), 5)}$ 衝突作用後に火災を受けるコンクリート構造物の安全性評価手法 の構築に資するべく, 本研究では, 鉛直荷重を支持する鉄筋コンク リート造壁（以下， $\mathrm{RC}$ 造壁と略寸）を対象として，剛飛翔体の衝 突によって局部破壊が生じ，かつ衝突面側から火災加熱を受ける場 合の構造耐火性を把握することを目的とした。本研究は, RC 造壁 の縮小試験体に対する高速衝突実験とその後の載荷加熱実験で構成 される。高速衝突実験ではコンクリートの短繊維補強の有無および 剛飛翔体の衝突速度を実験パラメータとした。そして, 無損傷の試 験体と高速衝突実験に供して局部破壊した試験体に対し，中心軸圧 縮力を作用させた状態で片面（局部破壊した試験体では衝突面）か ら加熱して，温度性状と構造耐火性を検討した。

\section{2. 鉄筋コンクリート造壁縮小試験体}

鉛直荷重を支持する $\mathrm{RC}$ 造壁を想定して, 試験体を計画・製作し た。試験体の計画では, 高速衝突実験に使用する高圧空気式飛翔体
* 清水建設(侏技術研究所 主任研究員 · 博十 (丁学)

** 防衛大学校システム工学群建設環境工学科 准教授 · 博士 (工学)

*** 千葉工業大学工学部建築都市環境学科＼cjkstart教授・工博
Senior Research Engineer, Institute of Technology, Shimizu Corporation, Dr. Eng. Assoc. Prof., Department of Civil and Environmental Engineering, School of Systems Engineering, National Defense Academy, Dr. Eng.

Prof., Department of Architecture and Civil Engineering, Faculty of Engineering, Chiba Institute of Technology, Dr. Eng. 
発射装置 6)に設置が可能な質量と形状・寸法を考慮した。また，当 該装置では, 現状, 試験体に軸方向力を作用させた状態での実験が できない。しかし, 本検討では衝突作用後に構造安定性を有してい ることが前提条件であることから, 仮決定した試験体仕様に関して, 軸方向力が作用している状態で高速衝突を受けた場合でも, 曲げ圧 縮破壊によって全体破壊しないことを計算で確認した。

\section{(1) 試験体の条件}

構造物内の人命や財産を守るという観点から，鉛直荷重を支持す る $\mathrm{RC}$ 造壁は，剛飛翔体の高速衝突によって裏面剥離が発生せず, かつ衝突後も荷重支持能力を保持していることが要求される。そこ で，鉛直荷重を支持している状態で水平方向から剛飛翔体の高速衝 突を受けて表面破壊が生じても，全体破壊しないことを条件として 試験体を設計する。具体的には, 高速衝突時の断面欠損によって残 存断面に急速に増加寸る軸方向力（以下，衝撃軸方向力と言う）, お よび衝突による水平力によって急速に生じる曲げモーメント（以下， 衝撃曲げモーメントと言う) が同時に作用した場合に, 曲げ圧縮破 壊が生じない試験体であることを条件とする。

\section{(2) 試験体の計画仕様}

試験体は高速衝突実験に使用する実験装置への設置が可能な質量 と形状・寸法を条件として，質量が約 $50 \mathrm{~kg}$ で，図 1 に示すように 幅 $300 \mathrm{~mm} \times$ 高さ $800 \mathrm{~mm} \times$ 厚さ $80 \mathrm{~mm}$, 壁厚と高さの比が $1 / 10$ の 鉄筋コンクリート板を計画した。既往の実験 3),4) と関連性を持たせ るため, コンクリートの設計基準強度 $\left(\mathrm{F}_{\mathrm{c}}\right)$ は $24 \mathrm{~N} / \mathrm{mm}^{2}$ としてポ リプロピレン短繊維（以下，PP 短繊維と略す）による補強の有無 をパラメータとし，鉄筋は D6（SD295A）を使用する。鉄筋は，縦 横 $85 \mathrm{~mm}$ 間隔の格子状に配した複配筋で, 縦筋比 (主筋) と横筋比 はいずれも $0.93 \%$, 縦筋のかぶり厚さは $15 \mathrm{~mm}$, 試験体表面から縦 筋の重心までの距離は $18 \mathrm{~mm}$ とする。試験体の支持・荷重条件は, 上端をピン・ローラー, 下端をピンとした単純支持として, 長期許 容軸力（=断面積 $\times \mathrm{Fc} / 3 ）$ が作用するものとする。剛飛翔体は, 先端形状が直径 $25 \mathrm{~mm}$ の半球型で, 質量が $46 \mathrm{~g}$ の鋼製（SS400）と し, 試験体壁面に垂直に衝突するものとする。剛飛翔体の衝突速度 は，本検討における試験体仕様とほぼ同等な既往の実験 3),4),6)から， 裏面剥離は発生せずに表面破壊のみが生じる衝突速度として, 短緎 維補強無しのプレーンコンクリート板を対象とした $215 \mathrm{~m} / \mathrm{s}$ と短繊 維補強コンクリート板を対象とした $315 \mathrm{~m} / \mathrm{s}$ の 2 水準とする。

\section{（3）衝撃荷重に対する耐力の検討}

\section{(1)試験体の表面破壊形状}

剛飛翔体の衝突によって表面破壊した試験体を図 2 のようにモデ ル化する。図中， $\mathrm{t}_{\mathrm{sp}}$ と $\mathrm{D}_{\mathrm{sp}}$ はそれぞれ表面破壊の貫入深さと直径を 示し， b， D および $\mathrm{H}$ はそれぞれ壁の幅・厚さ・高さを示す。

衝撃荷重に対する耐力の検討は 衝突速度 $215,315 \mathrm{~m} / \mathrm{s}$ の 2 ケー スについて行う。各々の表面破壊形状は既往の実験結果 3)を参照し, 衝突速度 $215 \mathrm{~m} / \mathrm{s}$ についてはプレーンコンクリート板の $\mathrm{t}_{\mathrm{sp}}$ $=14.2 \mathrm{~mm}, \mathrm{D}_{\mathrm{sp}}=97.1 \mathrm{~mm}$ を, 衝突速度 $315 \mathrm{~m} / \mathrm{s}$ については短繊維補 強コンクリート板の $\mathrm{t}_{\mathrm{sp}}=23.3 \mathrm{~mm}, \mathrm{D}_{\mathrm{sp}}=94.8 \mathrm{~mm}$ を仮定する。

(2)衝撃軸方向力の算定方法

衝撃軸方向力は, 鉛直下向きの荷重が瞬間的に作用する壁を 1 質 点系構造モデルに置き換えた弾性応答振動解析によって算定する。

高速衝突によって表面破壊や裏面剥離が発生すると断面が久損す
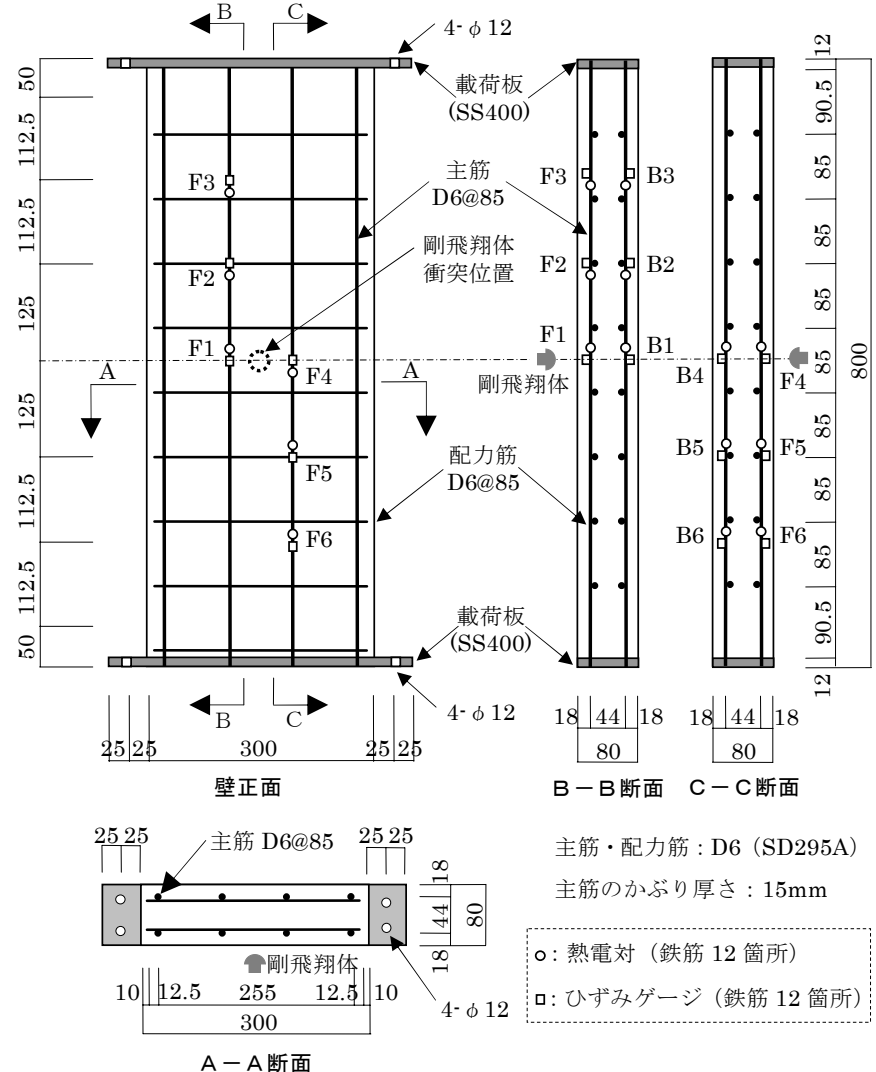

図 1 試験体の形状・寸法（単位：mm)

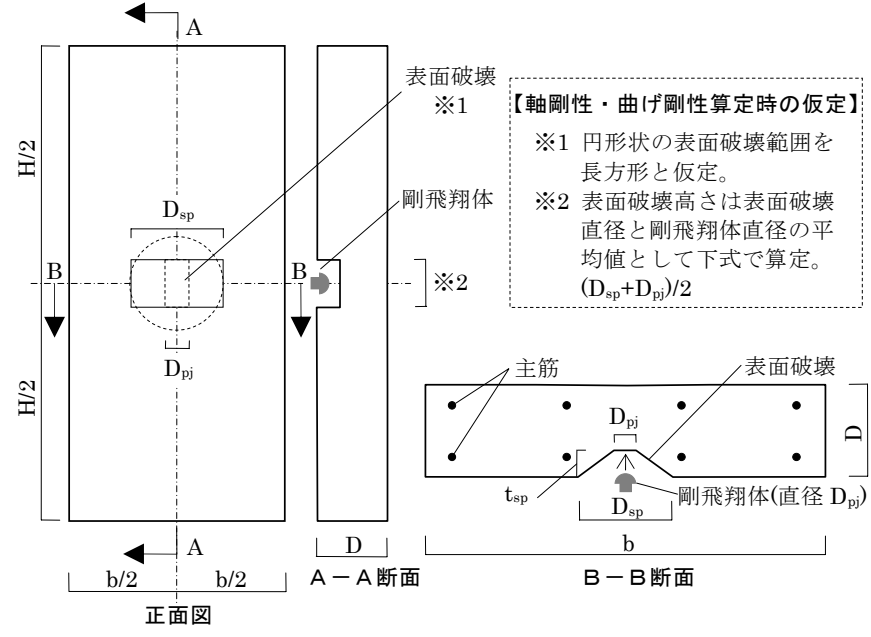

図 2 衝撃荷重に対する耐力の検討に用いる壁モデル

るため, 残存断面の負担する軸方向力は急速に増加する。そこで, 残存断面に作用する軸方向力を図 3 のようにモデル化する。時間 $t=0$ において, 断面欠損部分が負担していた荷重 $\Delta P_{N}$ が残存断面に瞬間 的に作用して，その後一定に保持される条件を仮定する。この荷重 条件において，上端が上下方向に自由に変位する部材に対する 1 質 点系モデルの弾性応答振動解析では, 動的倍率（静的応力に対する 動的応力の比）が式 1)で算定される 7)。動的応答は式 1)のように正 弦波（ $\left.0 \leqq L_{N} \leqq L_{N, \max }\right)$ となるため，衝撃軸方向力を算定する場合に は動的倍率の最大值を用いることとする。 $\Delta P_{N}$ に対する動的応答に よって試験体に作用する衝撃軸方向力は $\Delta P_{N}$ に最大動的倍率を乗 じて求められ，これを式 2)のように，衝突前から負担していた軸方 向力 $P_{N, o}$ に加えることで最大軸方向力を算定する。 


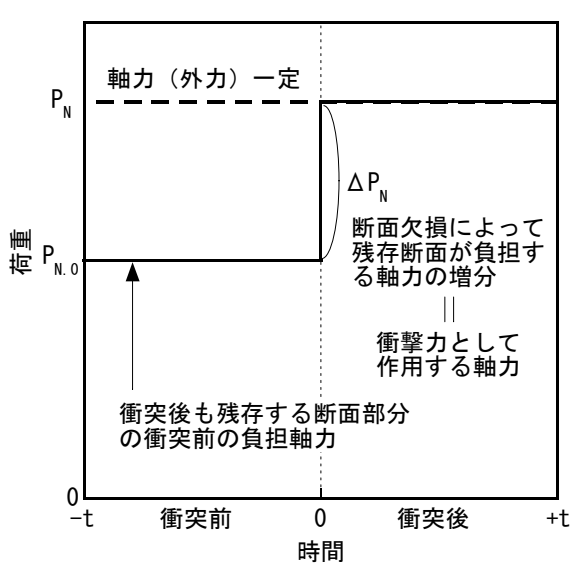

図 3 衝撃軸方向カの算定に用いる 軸方向カー時間関係の模式図

$L_{N}=1-\cos (\omega t) \quad(0 \leqq t)$

ここに,

$\omega=\frac{2 \pi}{T}, \quad T=2 \pi \sqrt{\frac{\alpha M}{1000 k}}, \quad \alpha=\frac{1}{3}$

$k=\frac{1}{\left\{E_{\mathrm{c}} A_{e, 0} /\left(H-H_{L D}\right)\right\}+\left\{E_{c}\left(A_{e, 0}-A_{L D}\right) / H_{L D}\right\}}$

$H_{L D}=\frac{D_{s p}+D_{p j}}{2}$

$P_{N, d}=P_{N, 0}+L_{N, \max } \Delta P_{N}$

ここに,

$P_{N, 0}=\frac{A_{e, 0}-A_{L D}}{3} f_{c}^{\prime}, \quad \Delta P_{N}=\frac{A_{L D}}{3} f_{c}^{\prime}$

$A_{L D}=\frac{D_{s p}+D_{p j}}{2} t_{s p}$

ここで, 式中の各記号の意味は以下のとおりである。

$A_{e, o}$ : ヤング係数比を考慮して鉄筋をコンクリートに変換した断面 欠損のない壁の等価断面積 $\left(\mathrm{mm}^{2}\right), A_{L D}$ : 局部破壊による壁の久損 断面積 $\left(\mathrm{mm}^{2}\right), D_{p j}$ : 飛翔体の直径 $(\mathrm{mm}), D_{s p}$ : 表面破壊直径 $(\mathrm{mm})$,

$E_{c}$ : コンクリートのヤング係数 $\left(\mathrm{N} / \mathrm{mm}^{2}\right), f_{c}{ }^{\prime}$ : コンクリートの压 縮強度(設計基準強度とする $\left(\mathrm{N} / \mathrm{mm}^{2}\right), H$ : 壁高さ $(\mathrm{mm}), H_{L D}$ : 壁 の損傷範囲の高さ $(\mathrm{mm}), k$ : 壁を 1 質点系モデルに置換する場合 の等価ばね定数 $(\mathrm{N} / \mathrm{mm}), L_{N}$ : 壁に作用する軸方向力に対する動 的倍率 (下付き文字 $\max$ は最大值を意味する), $M$ : 壁の質量 $(\mathrm{kg})$,

$P_{N, O}$ : 局部破壊後も残存する断面の局部破壊前の負担軸方向力 $(\mathrm{N})$,

$P_{N, d}$ : 動的応答を考慮した最大軸方向力 $(\mathrm{N}), \Delta P_{N}$ : 局部破壊によ る断面欠損で残存断面に付加される軸方向力(断面欠損部が負担 していた軸方向力 $(\mathrm{N}), T$ : 構造物の固有周期 $(\mathrm{s}), t$ : 時間 $(\mathrm{s}), t_{s p}$ : 貫入深さ $(\mathrm{mm}), \quad \alpha$ : 壁を 1 質点系モデルに置換する場合に等価質 量を算定するための係数 ${ }^{8)}, \omega$ : 壁の固有円振動数 $(1 / \mathrm{s})$

(3)衝撃曲げモーメントの算定方法

衝撃曲げモーメントは，水平方向に長方形パルス荷重が作用する 壁を 1 質点系構造モデルに置き換えた弾性応答振動解析によって算 定する。ここでは, 全断面を有効とした壁の断面 2 次モーメントを 用いた大きな動的倍率を算定して, 安全側の評価を行う。

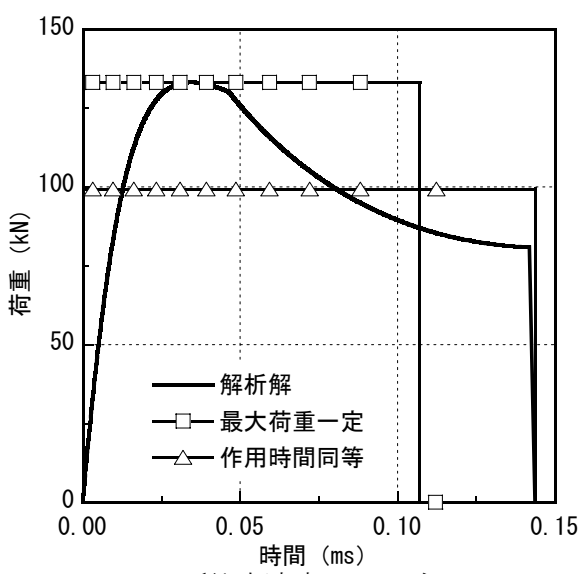

〔衝突速度 $315 \mathrm{~m} / \mathrm{s}$ ]

コンクリート板に剛飛翔体が衝突した場合の衝突荷重一時間関係 は，三輪らが提案した改良理論モデル998用いて算定する。このモ デルは，飛翔体の貫入量を剛飛翔体の運動エネルギーと仕事の釣り 合いから求めるもので，その算定過程において，衝突荷重（飛翔体 表面に作用する抵抗力）と飛翔体速度の経時変化が得られる。本章 (2)で述ベたコンクリートと剛飛翔体の条件に対して算定した衝突 速度 $215,315 \mathrm{~m} / \mathrm{s}$ の衝突荷重一時間関係，および衝撃曲げモーメン 卜を算定するために解析解を長方形パルス荷重に簡略化した衝突荷 重一時間関係を図 4 に示す。長方形パルス荷重は, 荷重を解析解の 最大值とした場合と荷重作用時間を解析解と同等とした場合の 2 種 類に関して，荷重時間面積が解析解と等価になるように設定した。

材軸に直交する方向の長方形パルス荷重をスパン中央に受ける単 純支持部材を 1 質点系モデルに置き換えた場合の動的倍率は式 3) で算定される 7)。式 3)は式 1) と同様に正弦波 $\left(-L_{H, \max } \leqq L_{H} \leqq L_{H, \max }\right)$ であるため，衝撃曲げモーメントは，動的倍率の最大值を用いて式 4)と式 5)によって算定する。なお，片側からパルス荷重を受けた壁 には，振動によって正負曲げモーメントが発生する。表面破壊は片 側のみで発生するため，主軸に対して部材断面が対称でないことか ら，ここでは正負曲げモーメントの双方に対して検討を行う。

$$
\begin{aligned}
& L_{H}=1-\cos (\omega t) \\
& \left(0 \leqq t \leqq t_{0}\right) \\
& L_{H}=\cos \left\{\omega\left(t-t_{0}\right)\right\}-\cos (\omega t) \quad\left(t_{0}<t\right) \\
& \text { ここに, } \\
& \omega=\frac{2 \pi}{T}, \quad T=2 \pi \sqrt{\frac{\alpha M}{1000 k}}, \quad \alpha=\frac{17}{35} \\
& k=\frac{48 E_{c} I_{0} I_{L D}}{\left(H-H_{L D}\right)^{3} I_{0}+\left\{H^{3}-\left(H-H_{L D}\right)^{3}\right\} I_{L D}} \\
& P_{H, d}=L_{H, \max } P_{H} \\
& M_{H, d}=\frac{P_{H, d} H}{4}
\end{aligned}
$$

ここで，式中の各記号の意味は以下のとおりである。

$I_{0}$ : 断面欠損のない壁の断面 2 次モーメント(全断面有効 $)\left(\mathrm{mm}^{4}\right)$, $I_{L D}$ : 断面欠損した部分の断面 2 次モーメント $\left(\mathrm{mm}^{4}\right), L_{H}$ : 壁に 
作用する水平力に対する動的倍率 (下付き文字 max は最大值を意 味する), $M_{H, d}$ : 動的応答を考慮した最大曲げモーメント $(\mathrm{N} \cdot \mathrm{mm})$, $P_{H}$ : 飛翔体の衝突によって壁に作用する水平力 $(\mathrm{N}), P_{H, d}$ : 動的応 答を考慮した最大水平力 $(\mathrm{N}), t_{0}$ : 動的荷重の作用終了時間 $(\mathrm{s})$ (4)曲げモーメント一軸方向力関係の算定方法

コンクリートが高速で載荷されると，ひずみ速度効果によって圧 縮強度や引張強度が増加する ${ }^{10)}$ 。例えば, ひずみ速度が $10^{1}(1 / \mathrm{s})$ 程 度で，コンクリートや剛飛翔体の衝突条件などが本研究と概ね同等 な場合, 圧縮強度は 1.7 倍, 引張強度は 4.1 倍程度になる ${ }^{9)}$ 。 し し,ここでは安全側の評価をすべく,ひずみ速度効果は考慮しない。

鋁直荷重を受ける鉄筋コンクリート板の曲げモーメント一軸方向 力関係（以下， $\mathrm{M}-\mathrm{N}$ 関係と略す）は，局部破壊による断面欠損を 考慮するとともに, コンクリートの引張強度はゼロとして, 鉄筋コ ンクリート構造計算規準・同解説 ${ }^{11)}$ に準じて算定する。

(5)算定結果と試験体の全体破壊の判定

本章(2)に記述した試験体仕様で, 衝突速度が $215 \mathrm{~m} / \mathrm{s}$ と $315 \mathrm{~m} / \mathrm{s}$ に関して, 表面破壊が発生した場合の衝撃軸方向力および衝撃曲げ モーメントを算定した結果を表 1 に示す。また, 動的倍率の算定結 果を図 5 に示し, 長期許容応力度, 短期許容応力度および最大応力 度（コンクリートの圧縮強度を設計基準強度とした条件）の各条件 のもとに算定した $\mathrm{M}-\mathrm{N}$ 関係を図 6 に示す。図 6 には表 1 に示した 衝撃軸方向力と衝撃曲げモーメントを併せてプロットした。

図 6 において, 衝突速度 $215 \mathrm{~m} / \mathrm{s}$ の場合, 衝撃軸方向力と衝撃曲 げモーメントは短期許容応力度に関して算定された $\mathrm{M}-\mathrm{N}$ 関係の包 絡線内に入っている。衝突速度 $315 \mathrm{~m} / \mathrm{s}$ の場合は短期の $\mathrm{M}-\mathrm{N}$ 関係 を超えるが, 最大応力度に対して求めた $\mathrm{M}-\mathrm{N}$ 関係の包絡線内に入 っている。この結果から, 軸方向力作用下において衝突速度 $215 \mathrm{~m} / \mathrm{s}$ の剛飛翔体の衝突を受けてもプレーンコンクリート試験体は全体破 壊せず，同様に，衝突速度 $315 \mathrm{~m} / \mathrm{s}$ の剛飛翔体の衝突を受ける短繊
維補強コンクリート試験体も全体破壊しないと判断される。よって, 本章(2)で仮決定した試験体仕様を変更することなく, 計画仕様どお りの試験体を製作することとした。

\section{（4）試験体に使用したコンクリートおよび鉄筋}

試験体に使用したコンクリートは既往の実験 3),4) と同仕様とした。 使用材料を表 2 に, 調合を表 3 に示す。また, 圧縮強度と耐火実験 時の含水率を表 4 に示す。試験体に用いたコンクリートは，プレー ンコンクリート（PLAIN）と PP 短繊維をコンクリート体積に対し て外割りで $1.0 \mathrm{vol} \%$ 混入した短繊維補強コンクリート（PP10）の 2 種類である。設計基準強度が $24 \mathrm{~N} / \mathrm{mm}^{2}$ 相当になるように水セメン 卜比を $55.0 \%$ とした。空気量は空気量調整剤を使用して約 $5 \%$ に調 整する計画であったが，PLAIN が 3.7\%，PP10 が 5.7\%であった。 この影響で PP10 の圧縮強度が PLAIN よりも低くなったと言える。 鉄筋には D6（SD295A）を使用した。使用した鉄筋の降伏点と降 伏ひずみの実測值は，それぞれ $342 \mathrm{~N} / \mathrm{mm}^{2} ， 2060 \mu$ であった。

\section{(5) 試験体の種類}

試験体の種類を表 5 に示す。試験体は, PLAIN を使用したもの が 2 体，PP10を使用したものが 3 体である。試験体名はコンクリ ートの種類, 高速衝突の有無と衝突速度を示寸表記とした。「衝突な し」と「衝突速度 $215 \mathrm{~m} / \mathrm{s}$ 」の条件に対しては, PLAIN と PP10 の双方に関して各 1 体ずつ実験を実施した。また,「衝突速度 $315 \mathrm{~m} / \mathrm{s} 」$ の条件に対しては, 既往の実験において裏面剥離しなかっ たPP10 に関して 1 体の実験を実施した。

\section{3. 実験方法 \\ (1) 高速衝突実験}

(1)実験装置

高速衝突実験には，図 7 に示寸高圧空気式飛翔体発射装置 6)を使 用した。剛飛翔体および試験体の設置状況を写真 1 に示す。発射装

表 1 衝撃軸方向カと衝撃曲げモーメントの算定結果

\begin{tabular}{|c|c|c|c|c|c|c|c|c|c|c|c|c|c|c|}
\hline \multirow{4}{*}{$\begin{array}{c}\text { 衝突速度 } \\
(\mathrm{m} / \mathrm{s})\end{array}$} & \multirow{3}{*}{\multicolumn{2}{|c|}{ 表面破壊 }} & \multicolumn{12}{|c|}{ 衝撃力 } \\
\hline & & & \multirow{2}{*}{\multicolumn{4}{|c|}{ 軸方向力 }} & \multicolumn{8}{|c|}{ 曲げモーメント } \\
\hline & & & & & & & \multicolumn{4}{|c|}{ 等価条件：最大荷重一定 } & \multicolumn{4}{|c|}{ 等価条件：作用時間同等 } \\
\hline & $\begin{array}{c}\mathrm{t}_{\mathrm{sp}} \\
(\mathrm{mm})\end{array}$ & $\begin{array}{c}\mathrm{D}_{\mathrm{sp}} \\
(\mathrm{mm})\end{array}$ & $\begin{array}{l}\mathrm{P}_{\mathrm{N}, 0} \\
(\mathrm{kN}) \\
\end{array}$ & $\begin{array}{l}\Delta \mathrm{P}_{\mathrm{N}} \\
(\mathrm{kN}) \\
\end{array}$ & $\mathrm{L}_{\mathrm{N}, \max }$ & $\begin{array}{l}\mathrm{P}_{\mathrm{N}, \mathrm{d}} \\
(\mathrm{kN}) \\
\end{array}$ & $\begin{array}{c}\mathrm{P}_{\mathrm{H}} \\
(\mathrm{kN}) \\
\end{array}$ & $\begin{array}{c}\mathrm{t}_{0} \\
(\mathrm{~ms})\end{array}$ & $\mathrm{L}_{\mathrm{H}, \max }$ & $\begin{array}{c}\mathrm{M}_{\mathrm{H}, \mathrm{d}} \\
(\mathrm{kN} \cdot \mathrm{m})\end{array}$ & $\begin{array}{c}\mathrm{P}_{\mathrm{H}} \\
(\mathrm{kN})\end{array}$ & $\begin{array}{c}\mathrm{t}_{0} \\
(\mathrm{~ms})\end{array}$ & $\mathrm{L}_{\mathrm{H}, \max }$ & $\begin{array}{c}\mathrm{M}_{\mathrm{H}, \mathrm{d}} \\
(\mathrm{kN} \cdot \mathrm{m})\end{array}$ \\
\hline 215 & 14.2 & 97.1 & 186 & 6.4 & 2.0 & 198 & 92 & 0.106 & 0.121 & 2.23 & 77 & 0.126 & 0.144 & 2.23 \\
\hline 315 & 23.3 & 94.8 & 182 & 10.3 & 2.0 & 202 & 133 & 0.107 & 0.122 & 3.26 & 99 & 0.144 & 0.164 & 3.26 \\
\hline
\end{tabular}

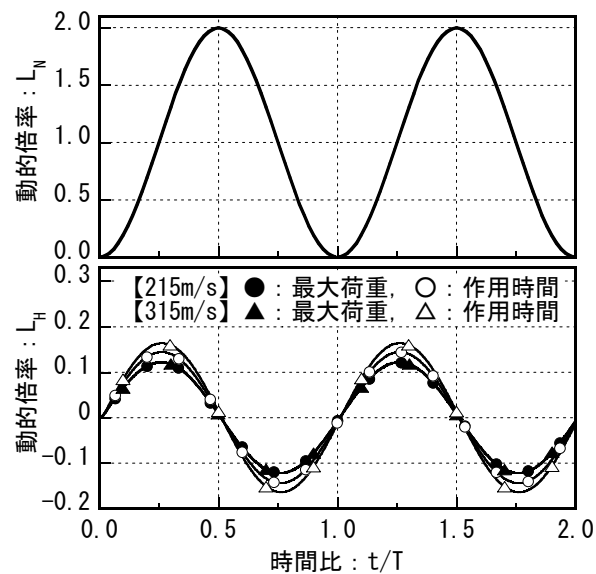

(上 : $L_{N}$, 下 : $L_{H}($ 凡例は等価条件を示す) $)$ 図 5 動的倍率
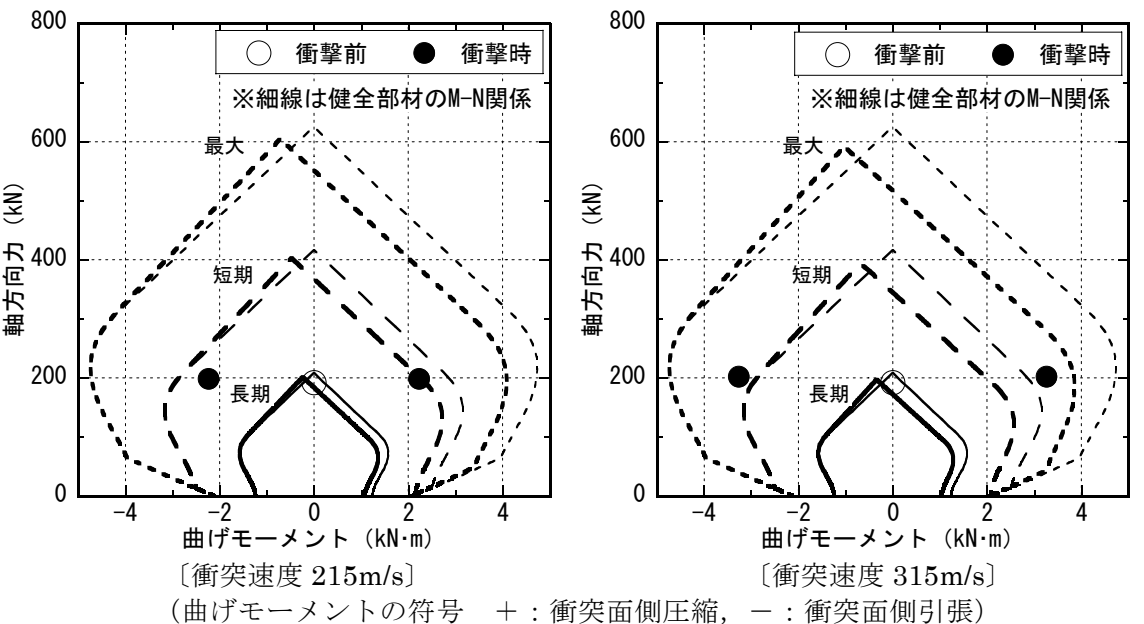

（曲げモーメントの符号 + : 衝突面側圧縮, 一 : 衝突面側引張）

図 6 表面破壊した壁の $M-N$ 関係と衝撃軸方向カ・衝撃曲げモーメントの関係 
置は, 圧縮器・増圧器・エアチャンバー・発射管 (長さ $12 \mathrm{~m}$, 内径 $35 \mathrm{~mm}$ ）で構成されており, 圧縮空気で飛翔体を発射・加速する。 衝突速度は発射装置の発射口に設置したレーザー式速度検出センサ 一で測定される。本実験では, 先端形状が直径 $25 \mathrm{~mm}$ の半球型で質 量が $46 \mathrm{~g}$ の鋼製（SS400）の剛飛翔体を使用した。

(2)試験体の支持方法

写真 1 に示すように, 試験体は, 剛飛翔体の衝突位置 (図 1 参照) から上下に $20 \mathrm{~cm}$ 離れた位置で，鋼製フレームと木製合板を介して クランプで固定した。剛飛翔体が衝突速度 $200 \mathrm{~m} / \mathrm{s}$ 以上でコンクリ 一ト板に衝突した場合, 板裏面に設置した荷重計が支点反力を検知 する前に局部破壊が終了することが確認されており 12)，本実験でも， 試験体の支持方法は局部破壊性状に影響しないと判断される。

(3)剛飛翔体の衝突速度

2 章(2)で述べたように, 既往の実験 3$), 4), 6$ から，表面破壊のみが生 じる衝突速度として,プレーンコンクリート板を対象とした $215 \mathrm{~m} / \mathrm{s}$ と短繊維補強コンクリート板を対象とした $315 \mathrm{~m} / \mathrm{s}$ の 2 水準とした。 (4)測定項目

剛飛翔体の発射速度, 表面破壊の貫入深さと直径, 裏面剥離の深 さと直径，および鉄筋のひずみ（図 1 参照）を測定した。なお，表 面破壞と裏面剥離の直径は, 破壊面の最大 ・最小・中間程度の長さ の測定值を平均して求めた。深さは破壊部の最大深さとした。

\section{（2）載荷加熱実験}

\section{(1)実験装置}

載荷加熱実験には，小型壁炉と加力装置で構成される実験装置を 使用した。実験装置を図 8 に, 実験装置に試験体を設置した状況を 写真 2 に示す。小型壁炉は都市ガスを燃料とするガスバーナー 4 基 で試験体を加熱するもので，炉内には炉内温度測定用の熱電対が 5 本設置されている。炉内温度はプログラム設定器によって所定の温 度に自動で制御される。加力装置は自己釣り合い型の鋼製フレーム の内側上部に $1000 \mathrm{kN}$ 荷重計と球座, 内側下部に $500 \mathrm{kN}$ オイルジ ヤッキと球座が取り付けられている。

(2)試験体の支持方法と断熱養生

試験体は，加力装置上下の球座の載荷板と試験体の載荷板をボル トで接合して支持した。試験体の加熱面の上下端は幅 $50 \mathrm{~mm}$ の範囲 を厚さ $25 \mathrm{~mm}$ のセラミックブランケット 4 層で被覆して断熱養生し た。また, 試験体の鉛直方向側面は, 試験体の全厚 $(80 \mathrm{~mm})$ を厚 さ $25 \mathrm{~mm}$ のセラミックブランケット 2 層で被覆して断熱養生した。 試験体に対する有効加熱面積は高さ $700 \mathrm{~mm} \times$ 幅 $300 \mathrm{~mm}$ である。

(3)載荷条件

加熱前に中心軸圧縮力を試験体に作用させ, 加熱中は試験体が破 壊するまで一定に保持した。中心軸圧縮力は, PLAIN と PP10のコ ンクリートの圧縮強度の実測值 $(\sigma \mathrm{b})$ を用いて次のように設定した。

PLAIN : $\sigma{ }_{\mathrm{b}} \times$ 断面積 $/ 3=45.9 \mathrm{~N} / \mathrm{mm}^{2} \times 24000 \mathrm{~mm}^{2} / 3$

$$
=367.2 \mathrm{kN}
$$
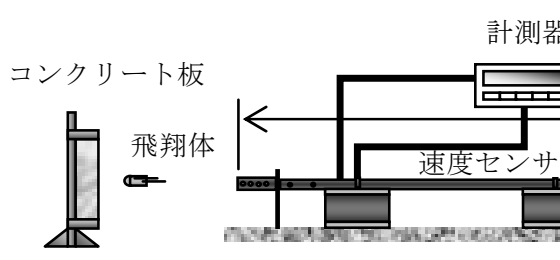

测器 $12 \mathrm{~m}$

$$
\begin{aligned}
\mathrm{PP} 10 ： \sigma_{\mathrm{b}} \times \text { 断面積 } / 3 & =30.6 \mathrm{~N} / \mathrm{mm}^{2} \times 24000 \mathrm{~mm}^{2} / 3 \\
& =244.8 \mathrm{kN}
\end{aligned}
$$

(4)加熱条件

試験体に対する加熱は衝突面を加熱面とし，炭化水素火災を模擬 した標準加熱温度時間曲線 13)（以下，H.C.曲線と略す）に準じた加

\begin{tabular}{|c|c|}
\hline 材料 & 種類・物性など \\
\hline 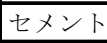 & 普通ポルトランドセメント \\
\hline 粗骨材 & 硬質砂岩（砕石 2005 , 青梅産）、表乾密度 : $2.65 \mathrm{~g} / \mathrm{cm}^{3}$ \\
\hline 細骨材 & 山砂（君津法木産山砂）、表乾密度 : $2.63 \mathrm{~g} / \mathrm{cm}^{3}$ \\
\hline 混和剤 & AE減水剂（標準形（I種））， $\mathrm{AE}$ 剂（I 種）、空気量調整剤 \\
\hline 短繊維 & \begin{tabular}{c|c} 
ポリプロピレン & 長さ $: 10 \mathrm{~mm}$, 直径: $0.048 \mathrm{~mm}$ \\
$(\mathrm{PP})$ & 密度 $: 0.91 \mathrm{~g} / \mathrm{cm}^{3}$, 引張強度 : $298 \mathrm{~N} / \mathrm{mm}^{2}$
\end{tabular} \\
\hline
\end{tabular}
熱を行った。加熱は試験体が破壞した時点で中止した。試験体の裏

\section{表 2 コンクリートの使用材料}

\begin{tabular}{|c|c|c|c|c|c|c|c|c|}
\hline \multirow[t]{2}{*}{ 調合名 } & \multirow{2}{*}{$\begin{array}{l}\text { W/C } \\
(\%) \\
\end{array}$} & \multirow{2}{*}{$\begin{array}{c}\text { 細骨材率 } \\
(\%)\end{array}$} & \multicolumn{5}{|c|}{ 単位量 ${ }^{* 1}\left(\mathrm{~kg} / \mathrm{m}^{3}\right)$} & \multirow{2}{*}{$\begin{array}{c}\text { PP短瀻維 } \\
\text { 混入率 }(\mathrm{vol} \%)\end{array}$} \\
\hline & & & $\mathrm{W}$ & C & $\mathrm{S}$ & G & $\mathrm{Ad}$ & \\
\hline PLAIN & \multirow{2}{*}{55} & \multirow{2}{*}{46} & \multirow{2}{*}{175} & \multirow{2}{*}{318} & \multirow{2}{*}{817} & \multirow{2}{*}{973} & 0.64 & - \\
\hline PP10 & & & & & & & 3.18 & 1.0 \\
\hline
\end{tabular}

表 3 コンクリートの調合

\begin{tabular}{|c|c|c|c|c|c|c|c|}
\hline \multirow{2}{*}{ 調合名 } & \multicolumn{2}{|c|}{ 材齢 $28^{* 1}$} & \multicolumn{2}{|c|}{$\begin{array}{l}\text { 衝突実験時※2 } \\
\text { (材齢約 } 50 \text { 日) } \\
\end{array}$} & \multicolumn{3}{|c|}{$\begin{array}{c}\text { 載荷加熱実験時※2 } \\
\text { (材齢約130日) }\end{array}$} \\
\hline & $\begin{array}{c}\sigma_{\mathrm{b}} \\
\left(\mathrm{N} / \mathrm{mm}^{2}\right) \\
\end{array}$ & \begin{tabular}{|c|}
$\mathrm{E}$ \\
$\left(\mathrm{N} / \mathrm{mm}^{2}\right)$ \\
\end{tabular} & $\begin{array}{c}\sigma_{\mathrm{b}} \\
\left(\mathrm{N} / \mathrm{mm}^{2}\right) \\
\end{array}$ & \begin{tabular}{|c}
$\mathrm{E}$ \\
$\left(\mathrm{N} / \mathrm{mm}^{2}\right.$ \\
\end{tabular} & $\begin{array}{c}\sigma_{\mathrm{b}} \\
\left(\mathrm{N} / \mathrm{mm}^{2}\right) \\
\end{array}$ & \begin{tabular}{|c|}
$\mathrm{E}$ \\
$\left(\mathrm{N} / \mathrm{mm}^{2}\right)$ \\
\end{tabular} & $\begin{array}{c}\begin{array}{c}\text { 含水率 } \\
(\%)\end{array} \\
\end{array}$ \\
\hline PLAIN & 35.2 & 38100 & 39.1 & 34900 & 45.9 & 36900 & 3.67 \\
\hline PP10 & 24.7 & 26000 & 25.3 & 25100 & 30.6 & 27000 & 4.08 \\
\hline
\end{tabular}

$※ 1 \mathrm{~W}:$ 水, $\mathrm{C}:$ セメント, $\mathrm{S}:$ 細骨材, $\mathrm{G}:$ 粗骨材, $\mathrm{Ad}: \mathrm{AE}$ 減水剤

表 4 コンクリートの圧縮強度および含水率

表 5 試験体の種類

\begin{tabular}{|c|c|c|c|}
\hline 試験体名 & コンクリート種類 & 高速衝突の有無 & 衝突速度 \\
\hline PLAIN-0 & PLAIN & なし & - \\
\hline PLAIN-2 & PLAIN & あり & $215 \mathrm{~m} / \mathrm{s}$ \\
\hline PP10-0 & PP10 & なし & - \\
\hline PP10-2 & PP10 & あり & $215 \mathrm{~m} / \mathrm{s}$ \\
\hline PP10-3 & PP10 & あり & $315 \mathrm{~m} / \mathrm{s}$ \\
\hline
\end{tabular}

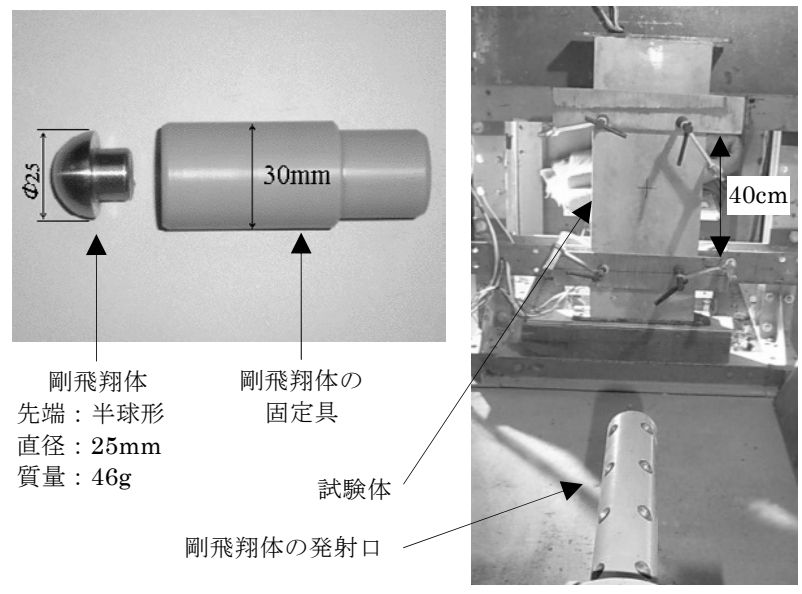

写真1＼cjkstart剛飛翔体および試験体の設置状態

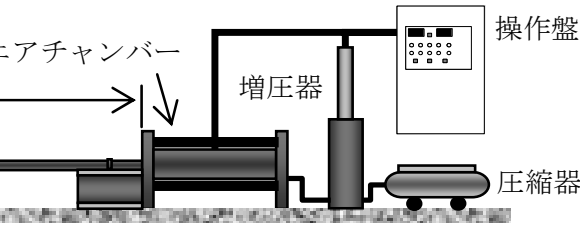

図 7 高圧空気式飛翔体発射装置の概要 
面は炉外の常温空気 $\left(31 \sim 34^{\circ} \mathrm{C}\right)$ に曝される条件とした。

\section{(5)測定項目}

炉内温度 5 点 (図 8 参照), 試験体内部の鉄筋温度 12 点（図 1 参 照）と裏面温度 3 点（図 8 参照), および載荷方向の変位 4 点と面 外方向の変位 6 点（図 8 参照）を測定した。

\section{4. 高速衝突実験結果および考察}

表 6 に各試験体における衝突速度および局部破壊の深さと直径を, 図 9 に主筋ひずみの測定結果を示す。ひずみの測定結果は上下対称 位置で概ね同等だったため, 計測不良点の少なかった F4〜 F6 と B4

〜B6 を示し, その中に計測不良点があった場合は対称位置のひず みを示した。写真 3 に高速衝突実験後の試験体の状況を載荷加熱実 験後の状況と併せて示寸。実験時の剛飛翔体の衝突速度は, 設定速 度 $215 \mathrm{~m} / \mathrm{s}$ に対して $212,214 \mathrm{~m} / \mathrm{s}$, 設定速度 $315 \mathrm{~m} / \mathrm{s}$ に対して $305 \mathrm{~m} / \mathrm{s}$ であった。以下では, 設定した衝突速度を単に衝突速度と言う。

\section{（1）局部破壊性状}

衝突速度 $215 \mathrm{~m} / \mathrm{s}$ の PLAIN-2 と PP10-2 は貫入深さ $15,18 \mathrm{~mm}$, 直径 86, $66 \mathrm{~mm}$ の表面破壊にとどまった。裏面の状況は, PLAIN-2 において衝突点位置から放射状に伸びたひび割れと衝突点位置を中 心とした円状のひび割れが認められたが，PP10-2 では認められな かった (写真 3 参照)。この結果は, 既往の実験結果と同様に, PP 短繊維による補強が局部破壊の抑制に有効であることを示している。

一方, 衝突速度 315m/s の PP10-3 では表面破壊だけでなく, 裏 面剥離が発生した。今回と同仕様のコンクリートを用いて PP 短繊 維 $1 \mathrm{vol} \%$ で補強した幅 $50 \mathrm{~cm} \times$ 高さ $50 \mathrm{~cm} \times$ 厚さ $8 \mathrm{~cm}$ のコンクリー 卜板に関する既往の実験 3)では, 衝突速度 $315 \mathrm{~m} / \mathrm{s}$ で裏面剥離は生 じなかった。今回の裏面剥離は, コンクリートの空気量が多く, 圧 縮強度が既往の実験 $\left(37.6 \mathrm{~N} / \mathrm{mm}^{2}\right)$ よりも低かったことが原因とし て考えられる。また, 剛飛翔体の衝突によってコンクリート板内部 に生じる応力波 (圧縮波) は自由端で反射して引張応力を生じるが, 試験体幅がこの応力波とその反射に影響した可能性も考えられ，こ の点については今後の検討課題である。

\section{(2) 主筋のひずみ性状}

図 9 に示すように, 試験体高さ中央の引張ひずみは, PLAIN-2 と PP10-2 の裏面側（B4）および PP10-3 の衝突面側（F4）と裏面 側（B4）において，降伏ひずみの実測值 $2060 \mu$ を超えた。しかし， 中央から離れた位置のひずみ（F5,F6(F3)，B5(B2),B6）は $1000 \mu$

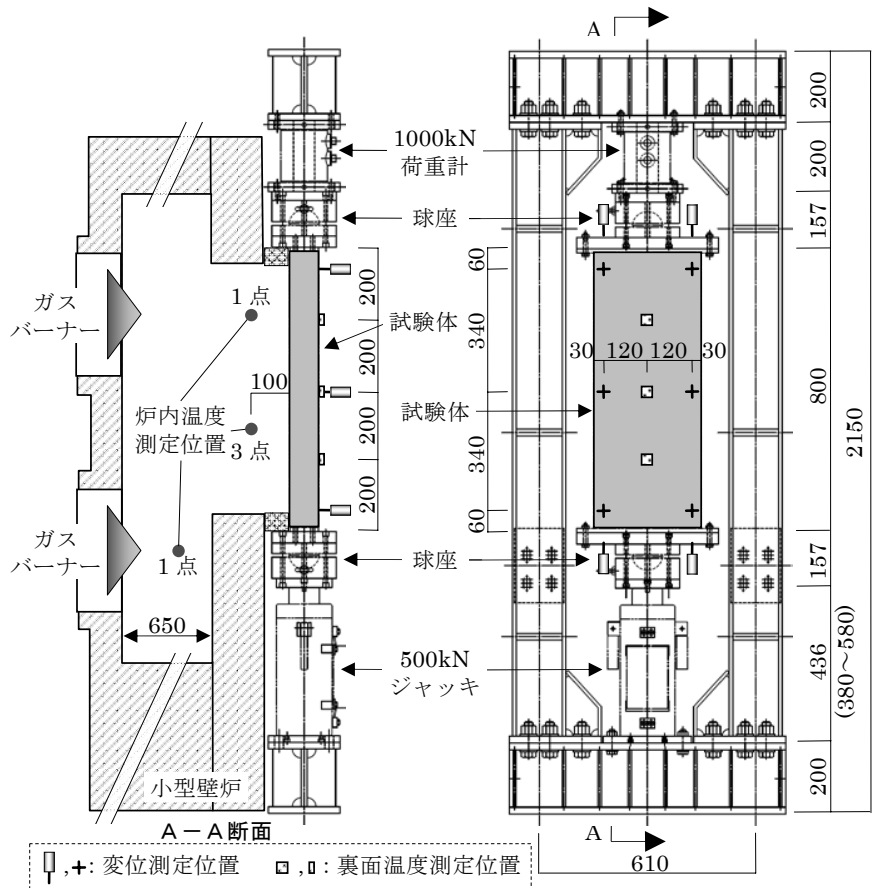

図 8 載荷加熱実験に使用した実験装置の概要（単位：mm）
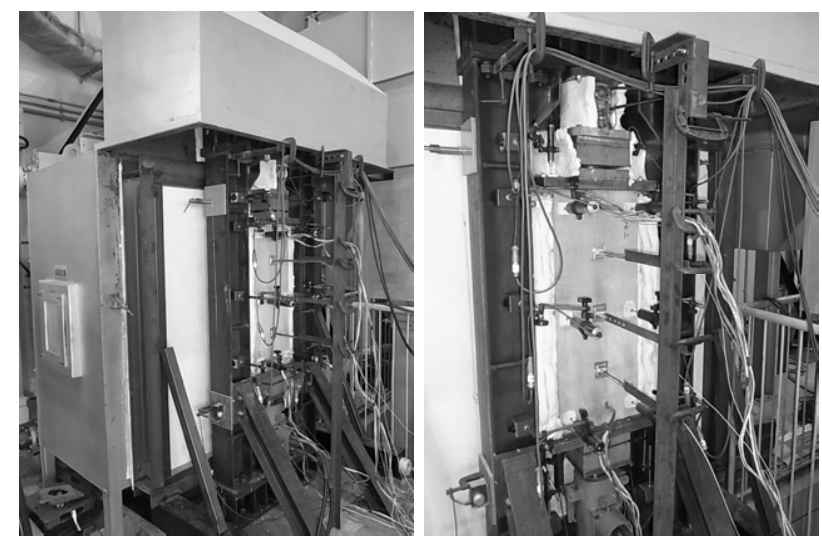

写真 2 載荷加熱実験装置と実験状況

表 6 衝突速度と局部破壊の深さと直径

\begin{tabular}{|c|c|c|c|c|c|}
\hline \multirow{2}{*}{ 試験体 } & 衝突速度 & \multicolumn{2}{|c|}{ 表面破壊 } & \multicolumn{2}{|c|}{ 裏面剥離 } \\
\cline { 3 - 6 } & $(\mathrm{m} / \mathrm{s})$ & 直径 $(\mathrm{mm})$ & 深さ $(\mathrm{mm})$ & 直径 $(\mathrm{mm})$ & 深さ $(\mathrm{mm})$ \\
\hline PLAIN-2 & 212 & 86 & 15 & - & - \\
\hline PP10-2 & 214 & 66 & 18 & - & - \\
\hline PP10-3 & 305 & 79 & 22 & 177 & 37 \\
\hline
\end{tabular}

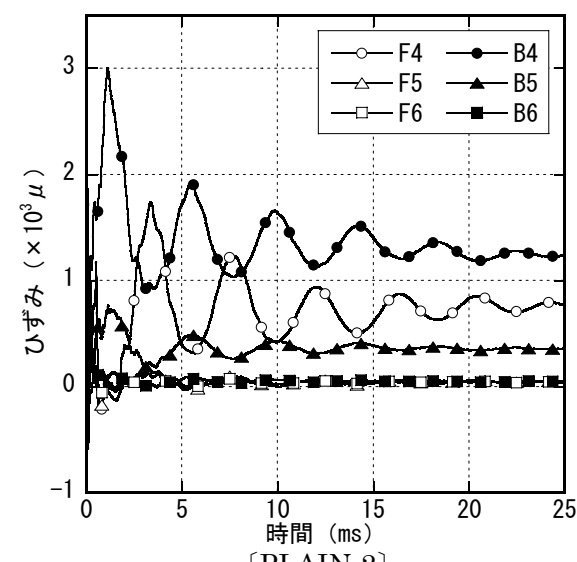

[PLAIN-2]

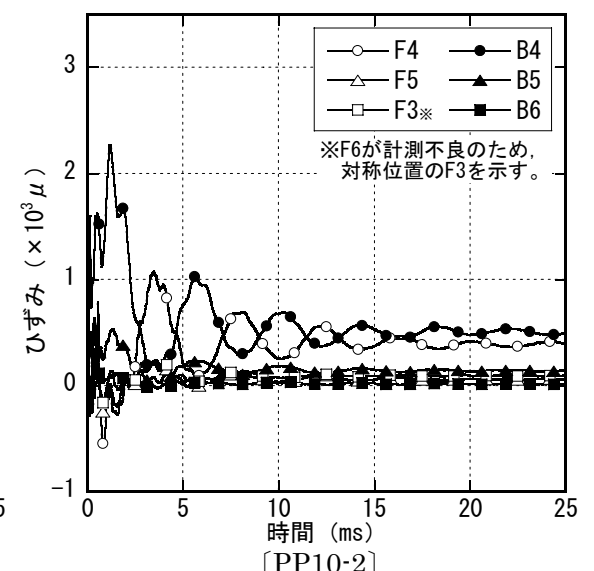

図 9 主筋のひずみの測定結果

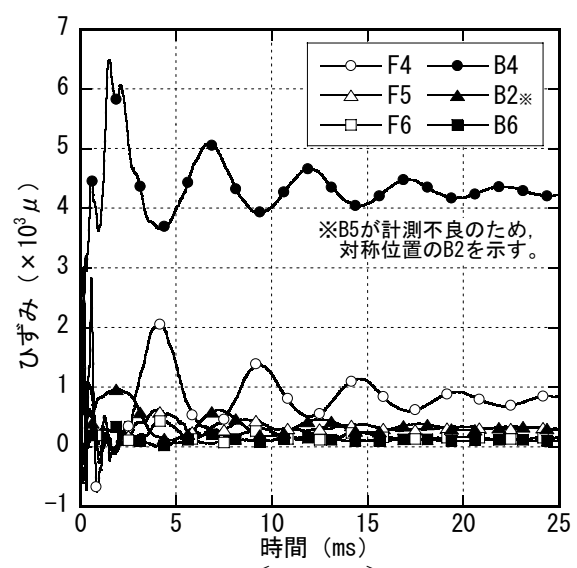

[PP10-3] 


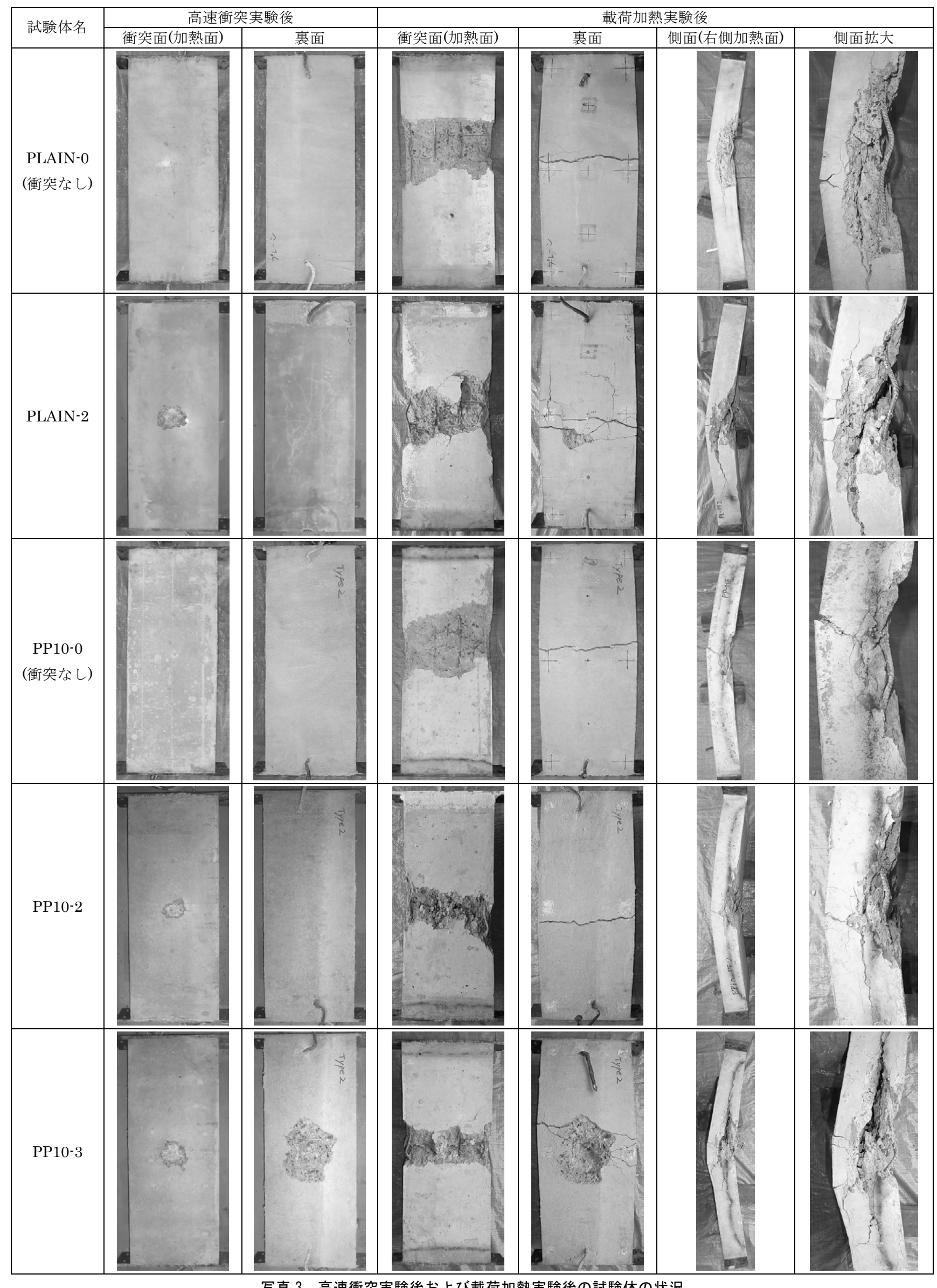


以下であり, 試験体には極めて局部的な曲げ変形が生じたと言える。 また，ひずみが概ね一定值に収束する $25 \mathrm{~ms}$ のひずみを残留ひず みとすると, 衝突面側と裏面側には引張ひずみが残留しており, 材 軸方向に開いたコンクリートのひび割れ等が影響していると言える。 高さ中央の裏面側の残留ひずみは衝突面側よりも大きく, PLAIN-2 で約 $1200 \mu$, PP10-2 で約 $500 \mu$, PP10-3 で約 $4200 \mu$ である。こ れらの值は, 裏面側主筋が履歴したひずみの最大值から降伏ひずみ の実測值 $2060 \mu$ を減じた值に近く, 主に塑性ひずみ成分だと言える。 なお, PLAIN-2 に比べて PP10-2 のひずみが若干小さいのは短緎 維補強の効果によるものと考えられ, 耐衝撃性能の向上における短 繊維補強の効果が前述のひび割れ発生状況と併せて再確認された。

\section{5. 載荷加熱実験結果および考察}

各試験体の載荷加熱実験前後の状況を前掲の写真 3 に示す。加熱 に先立って中心軸圧縮力を試験体に導入した時の試験体高さ中央と 中央から $125 \mathrm{~mm}$ 離れた位置の主筋のひずみ, および試験体高さ中 央における面外变位を図 10 に示し, 加熱時の炉内平均温度, 試験 体高さ中央における主筋温度と裏面温度, および鉛直変位と面外変 位を図 11 に示す。ひずみと変位は, 中心軸圧縮力の導入と加熱を 開始する各々の時点の初期值をゼロとして図示した。

\section{（1） 中心軸圧縮力導入時の主筋ひずみと面外変位}

高速衝突実験後の試験体には目視で確認できるような残留変形は 生じていなかった。しかし, 図 9 の主筋のひずみ測定結果に見られ るように, 衝突面側 (加熱面側) よりも裏面側の残留引張ひずみの 方が大きく，裏面側に凸の残留変形が生じていたと言える。図 10 に示すように，載荷による圧縮方向のひずみは加熱面側（F4,F5） よりも裏面側（B4,B5(B2)）の方が大きく, 裏面側に凸の残留変形 が減少したことを示している。また, 面外変位も加熱側に生じ, 所 定の荷重に至る前に, 変位が概ね一定值に収束している。以上から, 加熱に先だって行われた中心軸圧縮力の導入によって, 高速衝突実 験でコンクリートに生じたひび割れが閉じるなどして, 裏面側に凸 の残留変形が解消されたと推察される。

\section{（2）温度性状}

\section{(1)炉内温度}

炉内温度は加熱初期に H.C 曲線よりも若干低い傾向を示したが, 加熱開始後 7 分経過以降は概祀所定の温度となった。

\section{(2)加熱側主筋温度}

加熱側中央の主筋温度については, PP10-3 の温度が他の試験体 よりも高く, PP10-2 の温度が他の試験体よりも低い。PP10-3 の温 度が高くなったのは，表面破壊による断面欠損の大きさが影響して いると考えられる。PP10-2 の温度が PP10-0 よりも低くなった原因 として, 表面破壊部付近のコンクリートに微細なひび割れ等の損傷 が生じていたため, 損傷していないコンクリートに比べて, 表層の 熱コンダクタンスが低くなっていた可能性が考えられる ${ }^{4), 5) 。 ~}$

(3)裏面側主筋温度

裏面側中央の主筋温度については, PLAIN-2 の初期の温度の立ち 上がりが他の試験体に比べて早い。PLAIN-2 では, 裏面に放射状の ひび割れが観察されており，加熱面側から裏面に向けてひび割れが 貫通していたと考えられる。このひび割れが熱電対位置に偶然通じ ていたため, 加熱側のコンクリート中の水分が気化して発生した水 蒸気がひび割れを通じて熱電対位置に達した可能性が考えられる。

各試験体の $100^{\circ} \mathrm{C}$ 以の温度域における同時間での温度を比較す ると, PLAIN-2 $<$ PLAIN-0, PP10-2 $<$ PP10-0 となった。高速衝突 を受けて損傷している試験体の温度が無損傷の試験体よりも低くな ったのは, 高速衝突によって試験体内部に生じた斜めひび割れ（コ ンクリート板の厚さ方向の断面において衝突面側から裏面側に向か って押し抜きせん断ひび割れのような形で生じるひび割れであり， 裏面に正対した場合には円状のひび割れとして見える）が接触熱抵 抗になったためと考えられる ${ }^{4), 5)}$

(4)裏面温度

裏面中央の表面温度については, 温度上昇が $100^{\circ} \mathrm{C}$ 程度のため, 裏面側中央の主筋温度ほど明確な差異は認められない。ただし, PLAIN-2 と PP10-2 の温度では, 上述した考察に同じく, 斜めひび 割れの影響があると考えられる。なお，PP10-3 は裏面剥離してい たため, 中央部の温度は測定しなかった。

\section{（3）変形挙動}

\section{(1)変位の経時変化}

試験体には, 加熱開始後, 膨張方向に鉛直変位が生じるとともに, 加熱面側に凸の方向に面外変位を生じた。これは加熱面側のコンク リートの方が裏面側よりも高温で，熱膨張量が大きいためだと言え る。その後，加熱が進むに従い，鉛直変位は収縮方向に転じるとと もに，加熱面側に凸方向の面外変位が減少して裏面側に凸の方向に

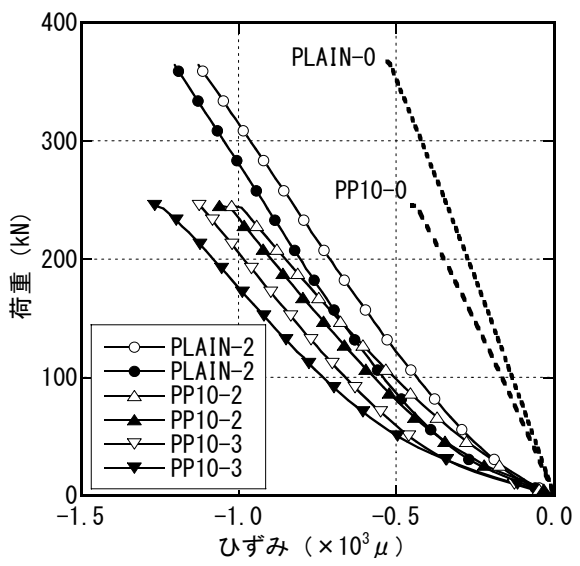

$\lceil$ F4 : $\bigcirc, \triangle, \nabla \quad \mathrm{B} 4:$

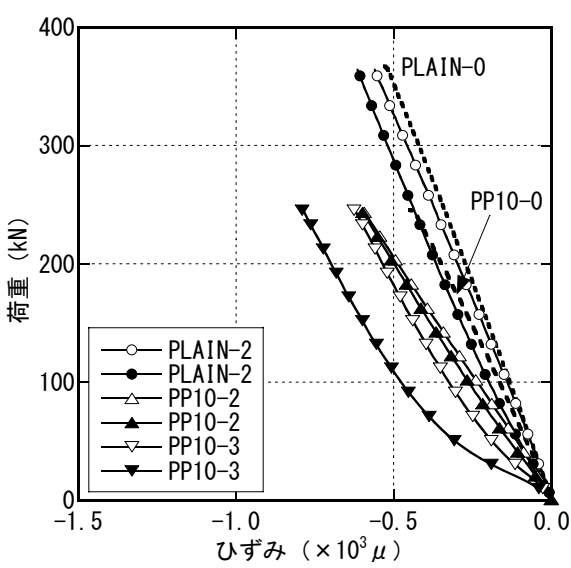

$\mathrm{F} 5$ : $\bigcirc, \triangle, \nabla \quad \mathrm{B} 5(\mathrm{~B} 2)$

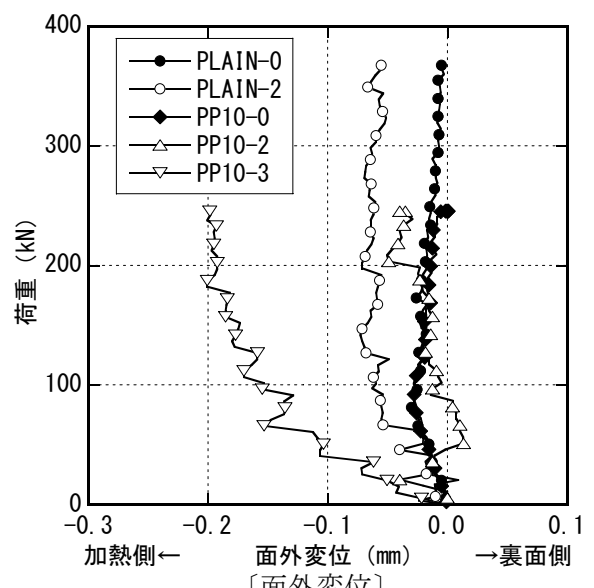

〔面外変位〕

図 10 載荷加熱実験の中心軸圧縮力導入時における主筋のひずみと試験体高さ中央位置の面外変位 

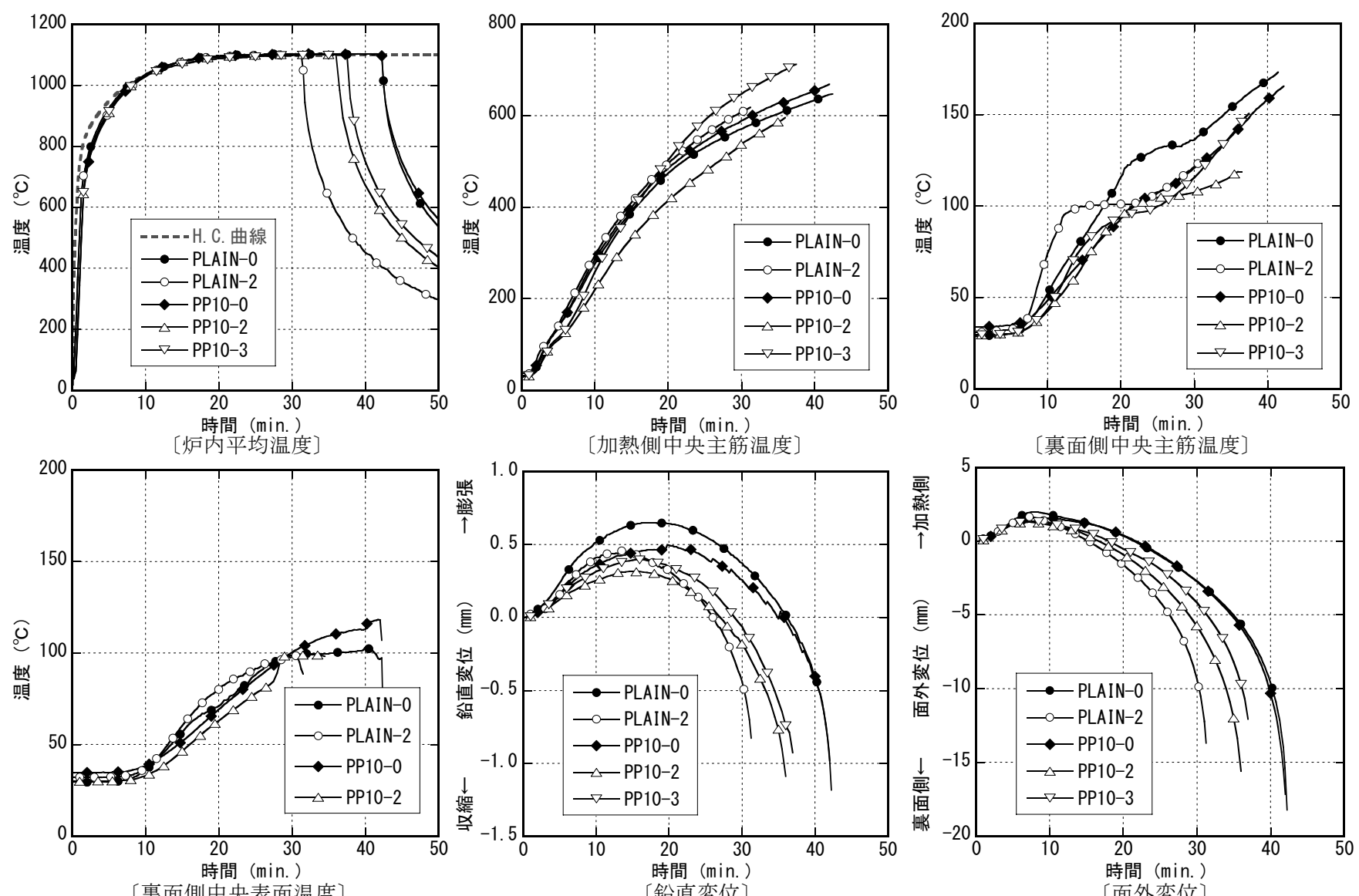

図 11 載荷加熱時における温度・変位の測定結果

転じた。これは加熱面側のコンクリートがさらに高温になることに よって圧縮強度とヤング係数が低下したこと, また, それに伴って, 部材の等価断面（ヤング係数の低下を考慮した断面）における重心 位置が裏面側に移動して偏心による曲げが生じたためだと言える。 そして, 収縮方向の鉛直変位と裏面側に凸方向の面外変位が増加の 傾向を示している中で, $\mathrm{P}-\delta$ 効果によって試験体高さ中央位置に おける曲げモーメントが増加し, 加熱面側のコンクリートが圧壊し て試験体が崩壊に至ったと考えられる。

なお, 上述の変形挙動から, 載荷加熱時に, 加熱面側主筋の応力 は圧縮で主に推移し, 裏面側主筋の応力は圧縮から引張に推移した と言える。そのため, 載荷加熱時の試験体の挙動に対する, 高速衝 突実験による主筋の引張側のひずみ履歴の影響は, 小さかったと考 えられる。また, 試験体は, 5 章(1)に述べたように高速衝突実験に よる裏面側に凸の残留変形が解消された状態から加熱され, さらに 加熱面側に凸の変形を生じたことから, 高速衝突実験時の残留変形 が載荷加熱実験結果に及ぼした影響は, 局部破壊の影響に比べて, 小さかったと考えられる。

\section{(2)鉛直変位}

PLAIN-0 と PP10-0 ならびに PLAIN-2 と PP10-2 の鋁直変位を 比較すると, 加熱初期の膨張方向の変位が PP10-0 $<$ PLAIN -0 ,

PP10-2<PLAIN-2 となっている。これは PP 短繊維が高温で消失 して微細な管状空隙を形成することにより, 疑似的なクラックを生 じてヤング係数が若干低下したためだと考えられる。PP 短繊維を 混入したコンクリートの高温時の熱膨張ひずみがプレーンコンクリ

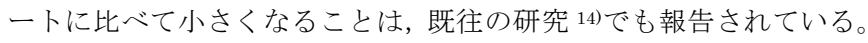

（4）崩壊時間

試験体が崩壊した時間は次のとおりであった。

PLAIN-0 : 42.5 分, PLAIN-2 : 31.5 分

PP10-0 : 42.5 分, PP10-2 : 36.5 分, PP10-3: 37.5 分

(1)PLAIN-0 と PP10-0 の比較

高速衝突実験に供さず無損傷の PLAIN-0 と PP10-0 は, 崩壊時間 が 42.5 分と同等であった。この結果は, コンクリートの圧縮強度が 異なっていても軸力比が同等で, 鉄筋量が今回の試験体程度であれ ば,試験体の崩壊時間が等しくなることを示していると考えられる。 (2)PLAIN-2 と PP10-2 の比較

PLAIN-2 の崩壊はPP10-2 よりも早くなった。図 2 に示した水平 断面モデルのように表面破壊の断面形状を台形と仮定して，断面欠 損面積を算定すると, PLAIN-2 が $833 \mathrm{~mm}^{2}$, PP10-2 が 819mm², PP10-3 が 1144mm² となる。PLAIN-2 と PP10-2 の断面欠損面積 は概ね等しいことから，表面破壊による断面欠損が崩壊時間の差異 に影響した可能性は小さい。

そこで, PLAIN-2 の崩壊が早くなった原因として, 剛飛翔体の高 速衝突による試験体内部の損傷の可能性が考えられる。剛飛翔体の 衝突によって, 表面破壊部付近のコンクリートには微細なひび割れ が生じ, 内部には斜めひび割れや放射状のひび割れが生じる。PP 短繊維補強にはこのようなひび割れの発生を抑制する効果がある。 この効果は, 写真 3 において, PLAIN-2 の裏面に見られるひび割れ が PP10-2 では見られないことからも確認できる。以上から, 試験 体内部のひび割れの程度の差異が, PLAIN-2 と PP10-2 の崩壊時間 の差に現われたと推察される。 
(3) PP10-2 と PP10-3 の比較

PP10-2 と PP10-3 では崩壊時間に大きな差がなかった。PP10-3 は PP10-2 よりも表面破壊による断面欠損が大きいことに加え, 裏 面剥離が発生したために, 断面欠損量はさらに大きい。水平断面に おいて裏面剥離による断面欠損形状を, 裏面側を底辺とする三角形 と仮定した場合, PP10-3 の裏面剥離による断面欠損面積は $3275 \mathrm{~mm}^{2}$ となる。衝突後の残存断面に対する軸力比は, 健全部材を 1 とすると, PP10-2 で 1.04, PP10-3 で 1.23 となり, 断面欠損に よる偏心を考えない場合は PP10-3 の方が不利であることがわかる。 しかし，いずれの試験体においても加熱面側（衝突面側）のコン クリートに圧壊が生じており, 試験体は, 片面加熱によって $\mathrm{P}-\delta$ 効果による曲げモーメントが増大し, 崩壊に至ったと言える。すな わち, 試験体の崩壊において, 軸剛性よりも曲げ剛性の低下が支配 的だったと考えられる。加熱が進行すると裏面側には引張応力が作 用するが, コンクリートは引張強度が小さいため, 裏面側のコンク リートが裏面剥離していても曲げ剛性は大きく変わらない。このた め, 裏面剥離が崩壊時間に対して大きく影響しなかったと言える。

一方, 水平断面において表面破壊による断面欠損形状を台形, 裏 面剥離による断面久損を三角形と仮定して, 主筋を考慮した常温時 における等価断面の重心を算定すると, 加熱面から重心までの距離 は PP10-2 で 41.05mm, PP10-3 で 37.45mm となる。実験に用い た載荷装置の軸方向力の作用軸は健全部材の重心（加熱面から 40mm）になるように設計されている。このため, 常温載荷状態に おいて, PP10-2 では加熱面の圧縮応力が裏面よりも大きく, PP10-3 では加熱面の圧縮応力が裏面よりも小さい応力分布状態になってい たと考えられる。また, コンクリートのヤング係数は加熱面側から 低下寸るため, 加熱中の等価断面の重心は裏面方向に移動する。こ の移動の速さが PP10-2 と PP10-3 で同等とすれば, 同じ経過時間 における $\mathrm{P}-\delta$ 効果による偏心曲げモーメントは PP10-2 の方が大 きくなるため, PP10-3 に比べて 1 分程度ではあるが, PP10-2 の 崩壊が早くなった可能性がある。図 11 の面外変位一時間関係にお いて, 同じ経過時間における PP10-2 の裏面側への変位が PP10-3 より大きいことは，これを裏付ける一つの結果だと考えられる。

\section{6. 結論}

鋁直荷重を支持する RC 造壁が剛飛翔体の高速衝突を受けて損傷 した後, 衝突面側から火災加熱を受けた場合の構造挙動を把握する ことを目的として, RC 造壁の縮小試験体に対する高速衝突実験と 載荷加熱実験を実施した。本検討結果は以下のようにまとめられる。

\section{(1) 高速衝突実験}

衝突速度 $215 \mathrm{~m} / \mathrm{s}$ では, PP 短繊維補強は, ひび割れの発生と主筋 のひずみ量を抑制し, 耐衝撃性能の向上に効果があることが確認さ れた。一方, 衝突速度 $315 \mathrm{~m} / \mathrm{s}$ では, 既往の検討結果 3) と異なり, PP 短繊維補強しても裏面剥離を防止できなかった。その原因とし て, 空気量の増大による圧縮強度の低下と試験体幅の影響が考えら れた。試験体幅の影響については今後の検討課題である。

\section{（2）載荷加熱実験}

剛飛翔体の高速衝突により, コンクリート板の表面破壊部付近に は微細なひび割れ等の損傷, 内部には斜めひび割れや放射状のひび 割れ等の損傷が生じる。本検討によって, 局部破壊した RC 造壁は
無損傷の壁に比べて崩壊時間が早くなることが確認された。また， 衝突速度 $215 \mathrm{~m} / \mathrm{s}$ の場合, PP 短繊維で補強した試験体の崩壊時間が 無補強よりも長くなり，PP 短繊維による補強が耐衝撃性能だけで なく構造耐火性の向上にも有効であることが確認できた。

PP 短繊維で補強した, 表面破壊のみ生じた試験体および表面破 壊と裏面剥離を生じた試験体の双方において, 崩壊は加熱面側（衝 突面側）のコンクリートの圧壊によって生じ，崩壊時間は概ね同じ であった。今回のように, 壁厚と主要支点間距離の比が $1 / 10$ 程度で ある RC 造壁が片面から加熱を受ける場合，軸剛性よりも曲げ剛性 の低下の方が構造耐火性に影響すると考えられる。このため, 本検 討では, 加熱が進行して引張側となる裏面側のコンクリートが剥離 していても，崩壊時間に大きく影響しなかったと言える。

\section{(3) 今後の課題}

現状では実験装置の制約などにより実大部材での実験が難しいこ とから, 本研究では縮小試験体に対する高速衝突実験と載荷加熱実 験を実施した。衝突作用後に火災を受けるコンクリート構造物の安 全性評価手法を構築するためには, さらなる実験検討とともに, 解 析的な検討も進める必要がある。今後は, 剛飛翔体の高速衝突を受 けた後の RC 造壁の火災時構造挙動を, 本実験結果との比較・検証 を行いながら，数值解析によって検討する予定である。

\section{参考文献}

1) 土木学会構造工学委員会衝撃問題研究小委員会: 構造物の衝撃挙動と設 計法, 構造工学シリーズ $6,1994.1$

2) 日本建築学会構造委員会応用力学運営委員会 : 衝突・爆発などの衝撃的 な外力による構造被害の低減化について考える, 2009 年度日本建築学会 大会 (東北) 構造部門 (応用力学) パネルディスカッション資料, 2009.8

3）森田武, 別府万寿博, 鈴木誠: 高速衝突を受けるポリプロピレン短繊維 補強コンクリートの耐衝撃性能, 日本建築学会構造系論文集, 第 78 巻 第 684 号, pp.319-327, 2013.2

4）森田武, 別府万寿博, 鈴木誠: 高速衝突を受けたコンクリート板の温度 性状, 日本建築学会構造系論文集, 第 78 巻 第 684 号, pp.2247-2256, 2013.12

5）森田武，別府万寿博，鈴木誠：剛飛翔体の高速衝突を受けたコンクリー 卜板の火㷋加熱に対する温度性状, 防衛施設学会平成 25 年度年次研究 発表梗概集，pp.35-44，2014.2

6）別府万寿博，三輪幸治，大野友則，塩見昌紀：鋼製剛飛翔体の高速衝突 を受けるコンクリート板の局部破壊に関する実験的研究, 土木学会論文 集, Vol.63, No.1, pp.178〜191, 2007.3

7）石川信隆, 大野友則, 藤掛一典, 別府万寿博 : 基礎からの衝撃工学, 森 北出版, 2008

8）小坪清真 : 土木振動学，森北出版，1995

9）三輪幸治, 別府万寿博, 大野友則, 伊東雅晴, 片山雅英 : 改良理論モデ ルによるコンクリート板の局部破壊評価法，土木学会論文集 A, Vol.65, No.4, pp.844-858, 2009.10

10）藤掛一典 : 高ひずみ速度下におけるコンクリートの引張・圧縮特性に関 する研究, 筑波大学博士論文, 1999.7

11）日本建築学会 : 鉄筋コンクリート構造計算規準・同解説，2010

12）三輪幸治：剛飛翔体の高速衝突を受けるコンクリート板の裏面剥離の発 生メカニズムと耐衝撃補強に関する研究, 防衛大学校博士論文, 2010

13) EUROCODE 1: Basics of design and actions on structures Part 2-2: Actions on structures exposed to fire, European Committee for Standardization, 1994

14）右田 周平, 前田 孝一, 平島 岳夫, 馬場 重彰: 高強度コンクリートの 高温時力学的特性に及ぼすポリプロピレン纎維の影響, 日本建築学会大 会学術講演梗概集, A-2, pp.11-12, 2011 


\title{
AN EXPERIMENTAL STUDY ON STRUCTURAL FIRE BEHAVIOR OF REINFORCED CONCRETE WALL AFTER HIGH VELOCITY IMPACT OF HARD PROJECTILE
}

\author{
Takeshi MORITA* , Masuhiro BEPPU** and Makoto SUZUKI***
}

* Senior Research Engineer, Institute of Technology, Shimizu Corporation, Dr. Eng.

** Assoc. Prof., Department of Civil and Environmental Engineering, School of Systems Engineering, National Defense Academy, Dr. Eng. *** Prof., Department of Architecture and Civil Engineering, Faculty of Engineering, Chiba Institute of Technology, Dr. Eng.

Projectiles would be released by an accident such as damage of turbine blades, and impinge on structures. Flying objects such as airplanes are also possible to be impact projectiles. These accidents occasionally cause fire, if there are fire load such as oil, fuel and any other combustible materials. The high velocity impact of a hard projectile on a reinforced concrete wall leads to the local damage, i.e. spalling, scabbing and perforation. The scabbing and perforation must be prevented, and the structure must not collapse under the local damage, in order to protect people and any other properties inside of the structure. Moreover, in case of fire after the impact, the structure must keep fire resistance to protect people and properties. Fire in or out of the structure must not spread to other compartments and spaces or into the structure, and the structure must not collapse under fire. Therefore it is necessary to investigate the influence of local damage on the fire resistance of structures.

As the first step, the authors have investigated the thermal insulation performance against fire of concrete plates damaged by the impact of a high velocity projectile. As the results of study, the authors have reported that the spalling and cracks in concrete plates produced by the impact lead to less effect on the thermal insulation performance of the concrete plates, and that concrete plates reinforced with polypropylene short fibers show the better thermal insulation performance than that of plain concrete plates.

The experimental study reported here was carried out as the second step of the research on impact and fire. This study focuses on the structural fire behavior of load bearing reinforced concrete walls exposed to fire after high velocity impact of a hard projectile. The study consists of the design of small scale reinforced concrete wall specimens, the high velocity impact experiment and the fire experiment on the specimen under centrally loaded after the high velocity impact.

The small scale reinforced concrete wall specimen was designed not to be collapsed by the high velocity impact under long allowable centrally loaded condition. To design the specimen, elastic response vibration analyses against horizontal and vertical impulse loads were done. Five specimens of $300 \mathrm{~mm}$ in width, $800 \mathrm{~mm}$ in height and $80 \mathrm{~mm}$ in thick were made with normal weight concrete of the design strength $24 \mathrm{MPa}$ and deformed steel bars (SD295A) of $6 \mathrm{~mm}$ in diameter. Polypropylene shot fibers of $0.05 \mathrm{~mm}$ in diameter and $10 \mathrm{~mm}$ in length were mixed into the concrete of the three in five specimens with an amount of one percent to the concrete volume.

The high velocity impact experiment was carried out on three specimens. A plain concrete specimen and a short fiber reinforced concrete specimen were impacted by a hard projectile of $215 \mathrm{~m} / \mathrm{s}$ in velocity and damaged with spalling. A short fiber reinforced concrete specimen was impacted by a hard projectile of $315 \mathrm{~m} / \mathrm{s}$ in velocity and damaged with spalling and scabbing.

The fire experiment under long allowable centrally loaded condition was carried out on five specimens. It was made clear that the local damage reduces the fire resistance of reinforced concrete walls. Two non-damaged specimens of plain concrete and short fiber reinforced concrete show the same fire resistance. In case of two specimens damaged with spalling, the short fiber reinforced concrete specimen shows the better fire resistance than the plain concrete specimen. In case of two specimens of short fiber reinforced concrete, the fire resistance of the specimen damaged with spalling and scabbing is the same as that of the specimen damaged with spalling only. 